\title{
Experimental rainwater divalent mercury speciation and photoreduction rates in the presence of halides and organic carbon
}

\author{
Xu Yang, ${ }^{1}$ Martin Jiskra, ${ }^{1,2}$ Jeroen E. Sonke ${ }^{1}$
}

${ }^{1}$ Géosciences Environnement Toulouse, Observatoire Midi-Pyrénées, CNRS/IRD/Université Toulouse III-Paul Sabatier, 31400 Toulouse, France

2Environmental Geosciences, University of Switzerland Basel, Bernoullistrasse 30, 4056 Basel, Switzerland

\section{Corresponding author:}

Jeroen E Sonke, PhD

CNRS research director

Midi-Pyrenees Observatory

Geoscience Environnement Toulouse

14 avenue Edouard Belin

31400 Toulouse, France

t.+33561332606

email: sonke@get.obs-mip.fr

Running title: Rainwater mercury speciation and photoreduction rates

Word count: 6720 
1 Title: Experimental rainwater divalent mercury speciation and photoreduction rates in the 2 presence of halides and organic carbon

3

4 Xu Yang, ${ }^{1}$ Martin Jiskra,,${ }^{1,2}$ Jeroen E. Sonke ${ }^{1}$

5

$6{ }^{1}$ Géosciences Environnement Toulouse, Observatoire Midi-Pyrénées, CNRS/IRD/Université 7 Toulouse III-Paul Sabatier, 31400 Toulouse, France

8

9 2Environmental Geosciences, University of Switzerland Basel, Bernoullistrasse 30, 4056 Basel, 10 Switzerland

11 


\section{Abstract}

Mercury $(\mathrm{Hg}$ ) photochemical redox reactions control atmospheric $\mathrm{Hg}$ lifetime and therefore play an important role in global $\mathrm{Hg}$ cycling. Oxidation of $\mathrm{Hg}(0)$ to $\mathrm{Hg}(\mathrm{II})$ is currently thought to be a Br-initiated two-stage reaction with end-products $\mathrm{HgBr}_{2}, \mathrm{HgBrOH}, \mathrm{HgBrONO}, \mathrm{HgBrOHO}$. Atmospheric photoreduction of these $\mathrm{Hg}$ (II) compounds can take place in both the gas and aqueous phase. Here we present new experimental observations on aqueous $\mathrm{Hg}(\mathrm{II})$ photoreduction rates in the presence of dissolved organic carbon and halides and compare the findings to rainfall $\mathrm{Hg}(\mathrm{II})$ photoreduction rates. The pseudo first-order, gross photoreduction rate constant, $\mathrm{k}_{\text {red }}$, for $0.5 \mu \mathrm{M} \mathrm{Hg}$ (II) in the presence of $0.5 \mathrm{mg} \mathrm{L}^{-1}$ of dissolved organic carbon (DOC) is $0.23 \mathrm{~h}^{-1}$, which is similar to the mean $\mathrm{k}_{\mathrm{red}}\left(0.15 \pm 0.01 \mathrm{~h}^{-1}(\sigma, \mathrm{n}=3)\right)$ in high altitude rainfall and at the lower end of the median $\mathrm{k}_{\mathrm{red}}\left(0.41 \mathrm{~h}^{-1}, \mathrm{n}=24\right)$ in continental and marine waters. Addition of bromide ( $\left.\mathrm{Br}^{-}\right)$to experimental $\mathrm{Hg}$ (II)-DOC solutions progressively inhibits $\mathrm{Hg}(\mathrm{II})$ photoreduction to reach $0.001 \mathrm{~h}^{-1}$ at total $\mathrm{Br}^{-}$of $10 \mathrm{mM}$. Halide substitution experiments give $\mathrm{Hg}(\mathrm{II}) \mathrm{X}_{\mathrm{n}}{ }^{(\mathrm{n}-2)}$ photoreduction rate constants of $0.016,0.004 \mathrm{~h}^{-1}$, and < detection limit for $\mathrm{X}=\mathrm{Cl}^{-}$, $\mathrm{Br}^{-}$, and $\mathrm{I}^{-}$respectively and reflect increasing stability of the $\mathrm{Hg}(\mathrm{II})$-halide complex. We calculate equilibrium $\mathrm{Hg}(\mathrm{II})$ speciation in urban and high-altitude rainfall using Visual Minteq, which indicates $\mathrm{Hg}$ (II)-DOC to be the dominant $\mathrm{Hg}$ species. The ensemble of observations suggests that atmospheric gaseous $\mathrm{HgBr}_{2}, \mathrm{HgCl}_{2}, \mathrm{HgBrNO}_{2}, \mathrm{HgBrHO}_{2}$ forms, scavenged by aqueous aerosols and cloud droplets, are converted to $\mathrm{Hg}$ (II)-DOC forms in rainfall due to abundant organic carbon in aerosols and cloud water. Eventual photoreduction of $\mathrm{Hg}(\mathrm{II})$-DOC in aqueous aerosols and clouds is, however, too slow to be relevant in global atmospheric $\mathrm{Hg}$ cycling. 


\section{Introduction}

Mercury $(\mathrm{Hg})$ is a ubiquitous heavy metal found throughout the atmosphere, hydrosphere, biosphere, geosphere and anthroposphere (Selin 2009). Neurotoxicity of $\mathrm{Hg}$ to humans and wildlife is of global concern due to widespread exposure via seafood consumption (Wolfe et al. 1998). Emission of $\mathrm{Hg}$ to the atmospheric boundary layer occurs mainly in the form of gaseous elemental $\operatorname{Hg}(0)$, and to a lesser extent (10\%) as gaseous oxidized $\mathrm{Hg}(\mathrm{II})$ and particle-bound $\operatorname{Hg}(\mathrm{P})$ from natural, anthropogenic and re-emitted sources (Schroeder and Munthe 1998, Futsaeter and Wilson 2013; Horowitz et al., 2017). $\operatorname{Hg}(0)$ is characterized by its low chemical reactivity and solubility, and long atmospheric lifetime of several months to over a year. $\operatorname{Hg}(0)$ is therefore fairly homogenously distributed throughout the atmosphere, and can be transported far from its emission sources and deposited to remote ecosystems (Horowitz et al. 2017, Jiskra et al. 2018, Saiz-Lopez et al. 2018). Oxidation of $\mathrm{Hg}(0)$ results in the formation of gaseous $\mathrm{Hg}(\mathrm{II})$ compounds, which are highly soluble, reactive and have a short atmospheric lifetime of days to weeks, and are readily scavenged by aerosols and clouds and returned to the Earth's surface by dry and wet deposition (Ariya et al. 2015, Saiz-Lopez et al. 2018). Atmospheric $\operatorname{Hg}$ (II) compounds can also be reduced back to $\operatorname{Hg}(0)$ in both the aqueous and gas phase and results in a prolonged lifetime of atmospheric $\mathrm{Hg}(0)$ (Munthe et al. 1991, Si and Ariya 2008, Saiz-Lopez et al. 2018). Redox processes of atmospheric $\mathrm{Hg}(0)$ and $\mathrm{Hg}(\mathrm{II})$ are considered as an important dynamic balance in global atmospheric $\mathrm{Hg}$ cycling and have been widely implemented in global atmospheric Hg chemistry and transport models (Shia et al., 1999; Dastoor and Larocque, 2004;

55 Travnikov and Ryaboshapko 2002, Selin et al. 2007, De Simone et al., 2014; Horowitz et al. 56 2017). Therefore, quantifying the kinetics and identifying the pathways of these reactions is 
crucial to better understand transport and deposition of atmospheric $\mathrm{Hg}$ to aquatic and terrestrial systems (Bash et al. 2014).

Production of atmospheric $\mathrm{Hg}(\mathrm{II})$ compounds is an important process in the atmosphere, as it is dominantly responsible for atmospheric $\mathrm{Hg}$ dry and wet deposition (Lin and Pehkonen 1999, Selin et al. 2007). Speciation of atmospheric $\mathrm{Hg}$ (II) is poorly understood, and has only identified as $\mathrm{HgCl}_{2}$ and $\mathrm{HgBr}_{2}$ in urban and indoor air and as $\mathrm{HgCl}_{2}$ in power plant plumes (Ernest et al. 2014, Deeds et al. 2015). Previous research has indicated that gas phase oxidation of atmospheric $\mathrm{Hg}(0)$ potentially involves various types of oxidants including $\mathrm{O}_{3}, \mathrm{OH}, \mathrm{HO}_{2}$, $\mathrm{H}_{2} \mathrm{O}_{2}, \mathrm{NO}_{3}$ and halogen species (Dibble et al. 2012, Peleg et al. 2015, Horowitz et al. 2017). Currently main oxidation of $\mathrm{Hg}(0)$ to $\mathrm{Hg}(\mathrm{II})$ is thought to be a Br-induced two-step reaction: first, $\mathrm{Hg}(0)$ is oxidized to $\mathrm{Hg}(\mathrm{I}) \mathrm{Br}$ by atomic bromide. Secondly, the relatively unstable $\mathrm{Hg}(\mathrm{I}) \mathrm{Br}$ is further oxidized to $\mathrm{Hg}(\mathrm{II})$ by other atmospheric radicals, such as $\mathrm{OH}, \mathrm{Br}, \mathrm{I}, \mathrm{Cl}, \mathrm{NO}_{2}, \mathrm{HO}_{2}, \mathrm{BrO}$, IO and $\mathrm{ClO}$, to produce dominant $\mathrm{Hg}$-halide end products $\mathrm{HgBr}_{2}, \mathrm{HgBrOH}, \mathrm{HgBrONO}$, $\mathrm{HgBrOHO}$ (Saiz-Lopez et al. 2018). These gaseous oxidized $\mathrm{Hg}(\mathrm{II})$ compounds are water soluble and therefore partition efficiently into cloud water and aqueous aerosols in general (Horowitz et al. 2017).

Photoreduction of dissolved $\mathrm{Hg}(\mathrm{II})$ bound to inorganic and organic ligands as well as with humic substances in terrestrial and marine aquatic systems has been widely identified as an important emission source of $\operatorname{Hg}(0)$ to the atmosphere (Ariya et al. 2015). Compared to direct photolysis of aqueous inorganic $\mathrm{Hg}$ complexes, the $\mathrm{Hg}$-humics photoreduction process is considered to be induced by light energy absorption of dissolved humic substances followed by a primary or secondary reaction (Ravichandran 2004, Zhang 2006). The primary reaction is known as ligand to metal charge transfer: first, the dissolved $\mathrm{Hg}(\mathrm{II})-\mathrm{DOM}$ complex is reduced to 
reactive and unstable $\mathrm{Hg}(\mathrm{I})$, second, the short-lived reactive intermediate $\mathrm{Hg}(\mathrm{I})$ quickly reduced to $\mathrm{Hg}(0)$ (Zheng and Hintelmann 2009). The secondary reaction has been proposed by Pehkonen and Lin (1998) via a two-step reduction process: first, dissolved $\mathrm{Hg}$ (II) is reduced to $\mathrm{Hg}$ (I) by $\mathrm{HO}_{2} \cdot$, second, $\mathrm{Hg}(\mathrm{I})$ is further reduced to $\mathrm{Hg}(0)$ by $\mathrm{HO}_{2}$. (Pehkonen and $\mathrm{Lin}$ 1998). The $\mathrm{Hg}$ photoreduction rates in natural waters are consistent with pseudo-first-order reaction kinetics and have been reported in a wide range of variability of 0.00125 to $2.5 \mathrm{~h}^{-1}$ relative to different light irradiation and DOM (Xiao et al. 1995, O'Driscoll et al. 2006, Qureshi et al. 2011).

Atmospheric $\mathrm{Hg}(\mathrm{II})$ photoreduction to $\mathrm{Hg}(0)$ in aqueous aerosols and clouds determines the lifetime of atmospheric $\mathrm{Hg}$ against wet deposition. The first global $\mathrm{Hg}$ chemistry and transport model (CTM) included $\mathrm{Hg}(\mathrm{II})$ reduction in the atmospheric aqueous phase by sulfite $\left(\mathrm{SO}_{3}{ }^{2-}\right)$, with $\mathrm{k}_{\mathrm{red}}$ of $0.6 \mathrm{~s}^{-1}\left(2160 \mathrm{~h}^{-1}\right)$ based on experimental work by Munthe et al. (Munthe et al. 1991, Shia et al. 1999). A later study that directly measured the reactant $\mathrm{HgSO}_{3}$ put into question the previously proposed reduction mechanism and rate constant, reporting $\mathrm{k}_{\mathrm{red}}$ of $0.0106 \mathrm{~s}^{-1}\left(38.2 \mathrm{~h}^{-1}\right)$ (Van Loon et al. 2000). Shia et al.'s CTM also included aqueous phase reduction of $\mathrm{Hg}$ (II) by hydroperoxyl, $\mathrm{HO}_{2}$, radicals, based on Pehkonen and Lin (1998) with $2^{\text {nd }}$ order $\mathrm{k}_{\text {red }}$ of $1.7^{*} 10^{4} \mathrm{M}^{-}$ ${ }^{1} \mathrm{~s}^{-1}$ (Pehkonen and Lin 1998, Shia et al. 1999). This reaction, which proceeds by a $\mathrm{Hg}(\mathrm{I})$ intermediate step has been questioned by Gardfeldt and Jonsson based on the rapid oxidation of the $\mathrm{Hg}$ (I) form back to $\mathrm{Hg}$ (II) (Gardfeldt et al. 2001). These aqueous phase $\mathrm{Hg}$ (II) reduction mechanisms have been gradually abandoned in $\mathrm{Hg}$ CTMs, to adopt a fitting approach where aqueous phase $\mathrm{Hg}(\mathrm{II})$ photoreduction rates are optimized to balance fast $\mathrm{Hg}(0)$ oxidation and reproduce global variability in observed $\mathrm{Hg}(0)$. (Travnikov and Ryaboshapko 2002, Selin et al. 2007, Horowitz et al. 2017). The fitted $\mathrm{k}_{\mathrm{red}}$ are typically on the order of $1.0 \mathrm{~h}^{-1}$, which corresponds to $\mathrm{Hg}$ (II) lifetimes in clouds and aqueous aerosol of 20 minutes (Selin et al. 2007). 
Despite the long history of experimental and model studies on atmospheric aqueous $\mathrm{Hg}$ (II)

104 photoreduction, the process has never been directly observed or quantified on natural samples.

105 Recently, we conducted the first aqueous phase photoreduction experiments of $\mathrm{Hg}$ (II) in rainfall

106 and observed slow values for $\mathrm{k}_{\mathrm{red}}$ in sub-urban $\left(0.05 \pm 0.02 \mathrm{~h}^{-1}, 1 \sigma, \mathrm{n}=9\right)$ and high-altitude rain

$107\left(0.15 \pm 0.01 \mathrm{~h}^{-1}, 1 \sigma, \mathrm{n}=3\right)$ (Saiz-Lopez et al. 2018). We evaluated the upper value of $\mathrm{k}_{\mathrm{red}}\left(0.15 \mathrm{~h}^{-}\right.$

$\left.10{ }^{1}{ }^{1}\right)$ for atmospheric aqueous $\mathrm{Hg}(\mathrm{II})$ photoreduction in the GEOS-Chem and GLEMOS Hg CTMs,

109 and found that the observation-based, slow $\mathrm{k}_{\mathrm{red}}$ leads to a major redox imbalance in the models.

110 Model results showed a strong negative bias in the size of the $\operatorname{Hg}(0)$ pool and a positive bias in

$111 \mathrm{Hg}(\mathrm{II})$ wet deposition (Saiz-Lopez et al., 2018). Based on theoretical chemistry computation of

$112 \mathrm{k}_{\text {red, }}$, we proposed that gas phase photoreduction of $\mathrm{Hg}(\mathrm{II}) \mathrm{BrX}$ to $\mathrm{Hg}(\mathrm{I}) \mathrm{Br}$ is an alternative and

113 fast reduction pathway for atmospheric $\mathrm{Hg}(\mathrm{II})$.

114

115 In this study we perform cation, anion and DOC analyses on the rainwater samples used by

116 Saiz-Lopez et al. (2018), in order to assess the equilibrium speciation of atmospheric aqueous

$117 \mathrm{Hg}(\mathrm{II})$. We present new experimental observations on the photoreduction rate constants of $\mathrm{Hg}$

118 bound to different types and concentrations of halides $(\mathrm{Cl}, \mathrm{Br}, \mathrm{I}$ ions $)$ and to $1 \mathrm{mg} . \mathrm{L}^{-1}$ dissolved

119 organic matter (DOM), in the form of fulvic acids. The objective of the present study is to better

120 understand $\mathrm{Hg}$ speciation and dynamics in atmospheric waters, from an equilibrium speciation

121 and photoreduction kinetics perspective. We aimed to identify in particular the nature of the slow

122 reducing $\mathrm{Hg}(\mathrm{II})$ complexes in rainfall.

123 


\section{Materials and methods}

126

127

128

129

130

\subsection{Sampling and experimental preparation}

Twenty-three experimental solutions containing $\mathrm{Hg}(\mathrm{II})$, DOM and halogen were prepared from commercially available NIST $3133 \mathrm{Hg}$, SRFA and halides (KCl, KBr, KI). The NIST SRM 3133 $\left(10,000 \mu \mathrm{g} \mathrm{g}^{-1} \mathrm{Hg}(\mathrm{II})\right.$ in $\left.10 \mathrm{vol} . \% \mathrm{HNO}_{3}\right)$ was used as $\mathrm{Hg}$ standard, from which more diluted stock solutions were prepared. Suwannee river fulvic acid (SRFA) was obtained from the International Humic Substances Society and dissolved in MQ water for use as a source of natural DOM (Maizel and Remucal 2017). KBr, KI and $\mathrm{KCl}$ salts were obtained from Sigma-Aldrich and diluted to $0.1 \mathrm{mM}$ stock solutions. Collection of 12 rainfall events was previously detailed in Saiz-Lopez et al. (2018) (Saiz-Lopez et al. 2018). In brief, rainfall was collected at two different sites: in sub-urban Toulouse, France $\left(n=8,1.479^{\circ} \mathrm{E}, 43.562^{\circ} \mathrm{N}\right)$ and at the high altitude $(2877 \mathrm{~m}$ a.s.1.) Pic du Midi Observatory $(\mathrm{PDM})$, France $\left(\mathrm{n}=2,0.142^{\circ} \mathrm{E}, 42.937^{\circ} \mathrm{N}\right)$ in the summer of 2017 (Fu et al. 2016, Marusczak et al. 2017). Large volume rain water was collected in 8 acid-cleaned polypropylene buckets simultaneously following Enrico et al. (2016) (Enrico et al. 2016). Single event samples were transferred to $2 \mathrm{~L}$ acid-cleaned pyrex bottles with GL45 caps. Selected samples were filtered on pre-burnt $47 \mathrm{~mm}$ quartz fiber filters (Millipore) in an acid-cleaned polycarbonate filtration unit (Fisher Scientific). Subsamples of filtered and unfiltered rainwater were taken for total $\mathrm{Hg}$ (THg, $10 \mathrm{~mL}$, acidified to 0.4 vol.\% with bi-distilled $9 \mathrm{~N} \mathrm{HCl}, 0.5$ vol\% $\mathrm{BrCl}), \mathrm{TOC} / \mathrm{DOC}(20 \mathrm{~mL}$, acidified to 0.4 vol.\% with $9 \mathrm{~N} \mathrm{HCl})$, anions, $\mathrm{pH}$ (30mL, unacidified), and major and trace metals $\left(10 \mathrm{~mL}\right.$, acidified to 2 vol.\% $\left.15.8 \mathrm{~N} \mathrm{HNO}_{3}\right)$. Remaining rain samples were stored in the refrigerator in the dark at $4^{\circ} \mathrm{C}$ until analysis.

\subsection{Photoreduction experiments}


Photochemical experiments were carried out in a $60 \mathrm{~mm}$ diameter, $0.5 \mathrm{~L}$ quartz reactor. For controlled indoor laboratory experiments (Xenon lamp light) a Sutter Instruments Lambda LS solar simulator with Perkin Elmer 300W PE300BUV Xenon lamp was used to shine artificial solar light, corresponding to a solar light unit, (in the UVA, UVB, UVC, VIS and IR range) in a $40 \mathrm{~mm}$ focused parallel beam through the reactor. Light intensities of key wavelengths of artificial solar irradiation were measured with a solar light PMA 2200 radiometer, including PMA 2106, PMA 2110 and PMA 2130 for UV-B (280-320nm), UVA(320-400nm) and visible

154 light (400-780nm) detector respectively (Supplementary Table S1). Outdoor experiments were 155 performed under natural sunlight (summertime, from 10-18h in full sun) outside the GET 156 laboratory building in Toulouse, France. No formal actinometric calibration of the experimental 157 set-up was performed. Instead we inter-compared Xe lamp experiments to outdoors full sunlight 158 experiments, which yielded similar $\mathrm{Hg}$ (II) reduction rates. Dynamic changes of natural UV and 159 visible irradiation intensities of these experiment days were simultaneously measured once per hour and put in Supplementary Table S2. Rainfall experiments were done at both ambient $\mathrm{Hg}$

161 levels, and at 2-40× augmented $\mathrm{Hg}$ levels. Experiments on artificial $\mathrm{Hg}$-halogen solutions were 162 carried out at higher $\mathrm{Hg}$ concentrations $(8-100 \mu \mathrm{g} / \mathrm{L})$ with the goal to analyze $\mathrm{Hg}$ stable isotope 163 fractionation (data not shown here). Although, the NIST3133 Hg standard solution is prepared in 16410 vol.\% $\mathrm{HNO}_{3}$, the amounts of $\mathrm{NO}_{3}{ }^{-}$introduced into the reactor are relative small, $\sim 16 \mu \mathrm{M}$. 165 Since photoreaction of $\mathrm{NO}_{3}{ }^{-}$can generate a cascade of radical reactions, we compared NIST $\mathrm{Hg}$ 166 additions to natural rainwater samples, and found no significant difference in $\mathrm{Hg}$ (II) reduction 167 rate, suggesting absence of $\mathrm{NO}_{3}{ }^{-}$related bias. Experimental $\mathrm{Hg} / \mathrm{halide}$ ratios were chosen to 168 approximate the range of natural ratios. Following sample addition, the reactor was wrapped with aluminum foil and equilibrated overnight. At the start of photoreduction experiment a 
sample aliquot $(\mathrm{t}=0)$ was taken and the reactor was exposed to natural sunlight outdoors (up to $8 \mathrm{~h}$ ) or to a solar simulator indoors (up to $48 \mathrm{~h}$ ). During the experiment the reactor was continuously purged with $\mathrm{Hg}$-free argon gas at $80 \mathrm{~mL} \mathrm{~min}^{-1}$ to remove product $\mathrm{Hg}(0)$ within minutes (O'Driscoll et al. 2006). Higher flow rates of $300 \mathrm{~mL} \mathrm{~min}^{-1}$ were tested and gave identical results, suggesting that the flow rate had no effect on observed the gross photoreduction rate. Subsamples were collected at different intervals over the course of the experiments. Dark control experiments were carried out under the same conditions in the absence of light irradiation. Analysis of the photoreduction product $\operatorname{Hg}(0)$ was attempted, but failed due to leaks on the quartz reactor cap, which is a common problem in these type of experiments.

\subsection{Hg, $\mathrm{pH}$, cations and anions, DOC measurement}

Samples were measured for total $\mathrm{Hg}$ concentration in duplicate following U.S. EPA method 1631 by cold vapor atomic fluorescence spectrometry (CV-AFS) in $5 \mathrm{ml}$ aliquots at fixed time steps. CV-AFS analysis accuracy was evaluated by regular analysis of the NRC ORMS-5 certified reference material $(26.2 \mathrm{ng} / \mathrm{L})$ with good results $(25.2 \pm 3.3,1 \sigma, \mathrm{n}=79)$. The $\mathrm{pH}$ of all the rain samples and experimental solutions were measured as soon as possible after collection and preparation using an Orion $\mathrm{pH}$ electrode, calibrated against NIST traceable standards of $\mathrm{pH}$ 4 and 7. Major cations in rainfall and experimental solutions were analyzed by high resolution ICP-MS (Thermo-Scientific Element-XR) at OMP, Toulouse, France. Anions were analyzed by ion exchange chromatography at EcoLab, Toulouse, France. DOC or TOC was measured on a total organic carbon analyzer (Shimadzu TOC VSCN) at GET, Toulouse, France. 


\subsection{Gross photoreduction kinetics}

193 The photoreduction experiments are considered as gross photoreduction due to the continuous

194 purging of $80 \mathrm{~mL} \mathrm{~min}{ }^{-1} \mathrm{Hg}$-free argon gas in the reactor, which removes product $\mathrm{Hg}(0)$ and 195 prevents it from re-oxidation to $\mathrm{Hg}$ (II). Dissolved $\mathrm{Hg}$ (II) is thought to be present as $\mathrm{Hg}$ (II)-ligand $196(\mathrm{Hg}(\mathrm{II}) \mathrm{L})$ complexes and reduced to $\mathrm{Hg}(0)$ in the presence of simulated solar light (Eq.1). The 197 whole reduction process is considered as a pseudo first-order reduction reaction with rate 198 constant, $\mathrm{k}_{\text {red }}$ (Eq.2) (Xiao et al. 1995, O'Driscoll et al. 2006, Qureshi et al. 2011).

$199 \mathrm{Hg}(\mathrm{II}) \mathrm{L}+\mathrm{hv} \rightarrow \mathrm{Hg}(0), \quad$ (Eq.1)

200

$\frac{\mathrm{d}[\mathrm{Hg}(\mathrm{II}) \mathrm{L}]}{\mathrm{dt}}=\mathrm{k}_{\mathrm{red}} \times[\mathrm{Hg}(\mathrm{II}) \mathrm{L}], \quad(\mathrm{Eq} .2)$

201 where $\mathrm{Hg}(\mathrm{II}) \mathrm{L}$ is the complexed inorganic $\mathrm{Hg}(\mathrm{II})$ in the solution, $\mathrm{Hg}(0)$ is the produced dissolved gaseous mercury (DGM) during the photoreduction process, hv is the light irradiation including natural sunlight or xenon lamp light. In order to see whether our photoreduction reactions are

pseudo first-order one, $\ln \frac{[\mathrm{Hg}(\mathrm{II}) \mathrm{L}]_{\mathrm{t}}}{[\mathrm{Hg}(\mathrm{II}) \mathrm{L}]_{0}}$ is plotted as a function of time (h) shown in Supplementary

Fig. S1a-e. Result show that generally the data show strong linear relationships ( $\mathrm{r}^{2}$ of $\left.0.69-1\right)$ and the pseudo-first order approach is therefore appropriate.

\subsection{Aqueous Hg speciation modeling}

The speciation of dissolved $\mathrm{Hg}$ in rain water and experimental solutions was calculated using the geochemical equilibrium modeling software Visual Minteq version 3.1 with default parameters.

210 The input data were based on $\mathrm{pH}$, temperature $\left(22^{\circ} \mathrm{C}\right), \mathrm{Hg}$ concentration, DOC concentration,

211 cation types and concentrations ( $\mathrm{Rb}, \mathrm{Mo}, \mathrm{Cd}, \mathrm{Ba}, \mathrm{La}, \mathrm{Tl}, \mathrm{Pb}, \mathrm{Th}, \mathrm{U}, \mathrm{Na}, \mathrm{Mg}, \mathrm{Al}, \mathrm{Ca}, \mathrm{V}, \mathrm{Cr}, \mathrm{Mn}$,

$212 \mathrm{Fe}, \mathrm{Co}, \mathrm{Ni}, \mathrm{Cu}, \mathrm{Zn}, \mathrm{Sr}$ and $\mathrm{K})$, anion types and concentrations $\left(\mathrm{F}^{-}, \mathrm{Cl}^{-}, \mathrm{N}-\mathrm{NO}^{2-}, \mathrm{Br}^{-}, \mathrm{N}^{-\mathrm{NO}_{3}}{ }^{-}, \mathrm{S}-\right.$ 
$\left.213 \mathrm{SO}_{4}{ }^{2-}, \mathrm{P}_{-} \mathrm{PO}_{4}{ }^{3-}\right)$. Trace metal, incl $\mathrm{Hg}(\mathrm{II})$, ion - DOC binding in Visual Minteq is based on the 214 Stockholm Humic Acid Model with the shmgeneric14.vdb database (Gustafsson 2001), and 215 which has been validated for $\mathrm{Hg}(\mathrm{II})$ elsewhere (Richard et al. 2016). Since atmospheric humic216 likes substances are generally low molecular weight compounds, and we use SRFA as a 217 surrogate, we simulate equilibrium $\mathrm{Hg}$ (II) binding to fulvic acids only with binding constant $218 \log \mathrm{K}_{\mathrm{HgFA} 2}$ of 6.7 , and $\mathrm{Lk} 2$ spread factor of 3.2. At our experimental rainfall $\mathrm{Hg} / \mathrm{DOC}$ ratios of 2190.5 to $6.8 \mathrm{ng}^{\mathrm{mg}} \mathrm{mg}^{-1}, \mathrm{Hg}$ (II) is coordinated to thiol groups on the DOC compounds (Haitzer et al. 220 2002), which is represented in visual Minteq by the $\mathrm{Hg}(\mathrm{II})-\mathrm{FA} 2$ complexes in the database and 221 equilibrium speciation results. The nominal $\mathrm{pH}$ was 4 in all experimental solutions, and ranged 222 from 3.8 to 6.3 in rainwater samples. No buffer was used to stabilize $\mathrm{pH}$, in order to avoid 223 photochemical artifacts, and in general drift in $\mathrm{pH}$ was limited to not more than 0.2 units.

\section{Results and Discussion}

\subsection{Photoreduction of aqueous $\mathrm{Hg}(\mathrm{II})$-halide, $\mathrm{Hg}(\mathrm{OH})_{2}$ and $\mathrm{Hg}(\mathrm{II})$-DOC}

Experimental photoreduction of $\mathrm{Hg}(\mathrm{II})$ in the presence of different types of halides and different ratios of $\mathrm{Br} / \mathrm{DOC}$ were carried out to explore the influence of halide types and $\mathrm{Br} / \mathrm{DOC}$ ratios on $\mathrm{Hg}$ (II) photoreduction rates (Table 1). The photoreduction kinetics are shown in Fig. 1a-c 230 indicate that different $\mathrm{Hg}$ (II) reduction rates occurred in all experiments including dark control 231 and photo-induced conditions. Table 2 (exp. A3-A6) shows estimated equilibrium $\mathrm{Hg}$ (II) 232 speciation at the start of the $0.1 \mathrm{mM}$ halogen experiments, indicating that $\mathrm{HgCl}_{2(\mathrm{aq})}(97 \%)$, $233 \mathrm{HgBr}_{2(\mathrm{aq})}(98 \%)$ and $\mathrm{HgI}_{2(\mathrm{aq})}(62 \%)+\mathrm{HgI}_{3}^{-}(\mathrm{aq})(37 \%)$ were dominant. Two types of $\mathrm{Hg}(\mathrm{II})$ control 234 experiments were carried out: exp. A1, presence of light, in MQ water, suggesting $\mathrm{Hg}(\mathrm{OH})_{2(\mathrm{aq})}$ as 
the dominant species (95\%), and exp. A2, A3, two dark controls (i.e. no light), in MQ with 95\% $\mathrm{Hg}(\mathrm{OH})_{2(\mathrm{aq})}$, and in presence of $0.2 \mathrm{mM} \mathrm{KBr}$ with $95 \% \mathrm{HgBr}_{2(\mathrm{aq})}$.

We observed low, but measurable, dark control reduction rates, $\mathrm{k}_{\text {red }}$, of $0.009 \mathrm{~h}^{-1}$ for the $\mathrm{Hg}(\mathrm{OH})_{2(\mathrm{aq})}$ complex in MQ water, and $0.001 \mathrm{~h}^{-1}$ for the $\mathrm{HgBr}_{2(\mathrm{aq})}$ complex (Fig. 1a, Table 1 experiments A2, A3). Dark reduction is generally attributed to abiotic, non-photochemical $\mathrm{Hg}(\mathrm{II})$ reduction and/or microbial $\mathrm{Hg}$ (II) reduction. Under full solar illumination by the Xe lamp, the stronger $\mathrm{Hg}$-halide complexes resulted in progressively slower $\mathrm{Hg}(\mathrm{II})$ photoreduction rates, $\mathrm{k}_{\text {red, }}$ of $0.016 \mathrm{~h}^{-1}, 0.004 \mathrm{~h}^{-1}$, for $\mathrm{HgCl}_{2}, \mathrm{HgBr}_{2}$, and undetectable for $\mathrm{HgI}_{2} / \mathrm{HgI}_{3}{ }^{-}$(Fig. 1b, Table 1 experiments A4, A5, A6). Experiments with $\mathrm{F}^{-}$ion were attempted, but unsuccessful as $\mathrm{F}^{-}$binds only weakly to $\mathrm{Hg}(\mathrm{II})$, resulting in dominant $\mathrm{Hg}(\mathrm{OH})_{2}$ complexes under all environmentally relevant $\mathrm{F}^{-}$concentrations. The light control experiment in absence of halides resulted in a fast 246 photoreduction rate of the $\mathrm{Hg}(\mathrm{OH})_{2 \text { (aq) }}$ complex in MQ water with $\mathrm{k}_{\text {red }}$ of $0.022 \mathrm{~h}^{-1}$ (Fig. 1a, Table 1 experiment A1). The fastest photoreduction was observed for $\mathrm{Hg}$-DOC complexes with $248 \mathrm{k}_{\text {red }}$ of $0.23 \mathrm{~h}^{-1}$ (Fig. 1a, Table 1 experiment A7), which is slightly lower than published rate constants under similar conditions: $\mathrm{k}_{\mathrm{red}}=0.47 \mathrm{~h}^{-1}$ (Bergquist and Blum 2007), and a literature review on aqueous $\mathrm{Hg}(\mathrm{II})$ photoreduction in continental and marine waters with median $\mathrm{k}_{\text {red }}=$ $0.41 \mathrm{~h}^{-1}$ (Qureshi et al. 2011). Duplicate experiments on $\mathrm{Hg}-\mathrm{DOC}$ and on $\mathrm{HgBr}_{2}$ species resulted in typical uncertainties of $30 \%(1 \sigma)$ on $\mathrm{k}_{\text {red. }}$ The dark control experiment with $\mathrm{Hg}(\mathrm{OH})_{2}$ (Fig. 1a, exp.A2) shows in fact a $\mathrm{k}_{\text {red }}$ that is faster $\left(0.009 \mathrm{~h}^{-1}\right)$ than some of the Hg-halide photoreduction 254 experiments, e.g. $\mathrm{HgBr}_{2}$ at $0.004 \mathrm{~h}^{-1}$. We suggest that the absence of stabilizing halide or DOC 255 ligands in solution renders this dark control not representative of the true experimental or 256 environmental dark $\mathrm{Hg}$ (II) reduction rates. The low dark control $\mathrm{k}_{\text {red }}$ of $0.001 \mathrm{~h}^{-1}$ of $\mathrm{Hg}(\mathrm{II})$ in the 257 presence of $\mathrm{Br}$ is likely more representative (exp. A3). 

transfer due to UVC absorption in the 200-300nm wavelength range can result in $\operatorname{Hg}(0)$ or $\mathrm{Hg}(\mathrm{I})$ products depending on $\mathrm{Hg} / \mathrm{halide}$ ratio and presence of oxygen (Horvath and Vogler 1993). At our experimental conditions, under low UVC irradiation, and with molar $\mathrm{Hg} /$ halide ratios $>100$ and in absence of oxygen, $\operatorname{Hg}(0)$ should be the product. Xiao et al. (1994), performed similar experiments on $\mathrm{Hg}(\mathrm{OH})_{2 \text { (aq) }}$ photoreduction at a higher $\mathrm{pH}$ of 7, finding $\mathrm{k}_{\text {red }}$ of $0.43 \mathrm{~h}^{-1}$ which is 7x faster than our observations (Xiao et al. 1994). The difference is likely due to a different experimental set-up, possibly due to their use of a more powerful (450W) medium pressure $\mathrm{Hg}$ vapor lamp. Compared to a Xe lamp which reproduces a solar light spectrum, medium pressure $\mathrm{Hg}$ vapor lamps emit primarily in the $200-600 \mathrm{~nm}$ region, with a particularly strong UVA line at $365.4 \mathrm{~nm}$.

\subsection{Photoreduction of $\mathrm{Hg}(\mathrm{II})$ in the presence of both halides and DOC}

Photoreduction kinetics of $\mathrm{Hg}$ vary at different $\mathrm{Br} / \mathrm{DOC}$ ratios in the presence of halide and

DOC (Fig. 1b). The pseudo first-order reduction rate constant $\mathrm{k}_{\text {red }}$ reached a high value of $0.23 \mathrm{~h}^{-}$ ${ }^{1}$ in the absence of $\mathrm{Br}^{-}$(Table 1, exp.A7). Addition of $\mathrm{Br}^{-}$at a low $\mathrm{Br}^{-} / \mathrm{DOC}$ ratio of $0.002 \mathrm{~mol} . \mathrm{g}^{-1}$ resulted in a decreased $\mathrm{k}_{\text {red }}$ to $0.14 \mathrm{~h}^{-1}$, and approximately $98 \%$ of $\mathrm{Hg}(\mathrm{II})$ was reduced during $48 \mathrm{~h}$ (Table 1, exp.A8). The continuous increase in $\mathrm{Br}^{-} / \mathrm{DOC}$ ratio further inhibits $\mathrm{Hg}$ photoreduction to reach $0.001 \mathrm{~h}^{-1}$ at a $\mathrm{Br} / \mathrm{DOC}$ ratio of $20 \mathrm{mol.g}^{-1}$ and results in only about $7 \%$ of $\mathrm{Hg}$ (II) $\operatorname{loss}$ in

277 the solution (Table 1, exp.A9-A12). Our experiments revealed that $\mathrm{k}_{\text {red }}$ had a strong linear 278 correlation with the Br-/DOC ratios during 48h (Fig.2).

279 Composition calculation of the dominant $\mathrm{Hg}(\mathrm{II})$ species in the $\mathrm{Br}^{-}+\mathrm{DOC}$ system are shown 280 in Table 2 and show a progressive change from DOC dominated to $\mathrm{Br}^{-}$dominated $\mathrm{Hg}$ (II) 
coordination with the increase of $\mathrm{Br} / \mathrm{DOC}$ from $0.002 \mathrm{~mol}^{-1} \mathrm{~g}^{-1}$ to $20 \mathrm{~mol} . \mathrm{g}^{-1}$. When $\mathrm{Br} / \mathrm{DOC}>0.2$ mol g-1, $\mathrm{HgBr}_{2(\mathrm{aq})}$ is the dominant species (84\%), whereas at $\mathrm{Br} / \mathrm{DOC}<0.2 \mathrm{~mol} \mathrm{~g}^{-1}, \mathrm{Hg}$-DOC dominates. These mixed ligand experiment show coherent behavior of $\mathrm{Hg}(\mathrm{II})$ photoreduction rates, varying between the fast $(\mathrm{Hg}-\mathrm{DOC})$ and slow $\left(\mathrm{HgBr}_{2}\right)$ end-members (Fig. 2). Additional experiments at $\mathrm{Cl}^{-} / \mathrm{DOC}$ of $0.2 \mathrm{~mol} \mathrm{~g}{ }^{-1}$, with calculated speciation of $\mathrm{HgCl}_{2}(48 \%)$ and $\mathrm{Hg}-\mathrm{DOC}$ $(50 \%)$, resulted in a $\mathrm{k}_{\mathrm{red}}$ of $0.16 \mathrm{~h}^{-1}$. An I/DOC $=0.2 \mathrm{~mol} \mathrm{~g}^{-1}$ experiment resulted in a slow $\mathrm{k}_{\mathrm{red}}$ of $0.0023 \mathrm{~h}^{-1}$ during the first $72 \mathrm{~h}$, followed by insignificant $\mathrm{Hg}$ (II) photoreduction from 72 to $168 \mathrm{~h}$ (Figure 1(c)). The decrease in $\mathrm{k}_{\text {red }}$ from 0.16 to 0.011 to $0.0023 \mathrm{~h}^{-1}$ for the $\mathrm{Cl}^{-}, \mathrm{Br}^{-}, \mathrm{I}^{-}$mixed ligand experiments in the presence of constant DOC concentration corroborates the role of the halide ion in stabilizing $\mathrm{Hg}(\mathrm{II})$ in solution ( $\mathrm{K}_{\text {eql }}$ increasing from $\mathrm{Cl}^{-}$to $\mathrm{Br}^{-}$to $\mathrm{I}^{-}$) , and effectively 291 inhibiting photoreduction relative to $\mathrm{Hg}$-DOC species. The inhibitory effect of halogen ligands on photoreduction can be explained by different photosensitizer properties of the halogens and DOC ligands. DOC contains chromophore moieties such as aromatic rings and conjugated double bonds which efficiently absorb UV-light at multiple wavelengths (Del Vecchio and Blough 2002). On the contrary, the ionic single bond of $\mathrm{Hg}(\mathrm{II})-\mathrm{X}$ has more restricted UV absorption properties, likely leading to lower photoreduction yields (Saiz-Lopez et al. 2018).

\subsection{Photoreduction of rainfall $\mathrm{Hg}(\mathrm{II})$}

299 We previously published experimental rainfall $\mathrm{Hg}$ (II) gross photoreduction rates, which ranged 300 from 0.016 to $0.072 \mathrm{~h}^{-1}$ (mean $0.051 \pm 0.019 \mathrm{~h}^{-1}, \sigma, \mathrm{n}=10$ ) in suburban Toulouse, and from 0.14 301 to $0.19 \mathrm{~h}^{-1}$ (mean $0.15 \pm 0.01 \mathrm{~h}^{-1}, \sigma, \mathrm{n}=3$ ) at the remote high-altitude PDM (Saiz-Lopez et al.

302 2018). Here we complete this dataset with rainfall chemistry data for the same samples, 303 including major cations, anions (including $\mathrm{Cl}^{-}, \mathrm{Br}^{-}$and $\mathrm{F}^{-}$, but not $\mathrm{I}^{-}$), $\mathrm{pH}$ and DOC (Table 1, 
experiments R1-R13). We use $\mathrm{V}$. Minteq to estimate the $\mathrm{Hg}(\mathrm{II})$ species distribution among inorganic $\left(\mathrm{F}^{-}, \mathrm{Cl}^{-}, \mathrm{Br}^{-}, \mathrm{NO}_{3}^{-}, \mathrm{SO}_{4}^{2-}, \mathrm{OH}^{-}\right)$and organic, DOC ligands, assuming that equilibrium conditions are met, and that the rainfall is saturated in $\mathrm{CO}_{2}$ with respect to an atmospheric $\mathrm{pCO}_{2}$ of 400 ppmv. Particulate $\mathrm{Hg}$ (II) forms are ignored in the speciation calculations based on the low $(<5 \%)$ particulate $\mathrm{Hg}$ detected by filtration . For $\mathrm{I}^{-}$, we assume a total concentration of $1.1 \mu \mathrm{g} \mathrm{L}^{-1}$, identical to the mean rainfall total I observed at PDM (Suess et al. 2019). In the V. Minteq speciation model we assumed atmospheric DOC to be in the form of strong fulvic-type acids (FA2). Speciation calculation results are summarized in Table 2, and indicate that in all rainfall samples $\mathrm{Hg}$ is bound to DOC, notably to the stronger FA2 type sites that represent phenolic, thiol and bidentate complexes with $\mathrm{Hg}(\mathrm{II})$. The $\mathrm{Hg} / \mathrm{DOC}$ concentration ratios we observe in rainfall range from 0.5 to $6.8 \mathrm{ng} \mathrm{mg}^{-1}$, indicating that $\mathrm{Hg}(\mathrm{II})$ is likely coordinated to thiol groups on the DOC compounds (Haitzer et al. 2002). Observed $\mathrm{Cl}^{-} / \mathrm{DOC}, \mathrm{Br}^{-} / \mathrm{DOC}$ and estimated I/DOC levels in rainfall range from 0.02 to $6 \times 10^{-7} \mathrm{~mol} / \mathrm{g}$, corroborating that the photoreduction kinetics should be dominated by the $\mathrm{Hg}(\mathrm{II})-\mathrm{DOC}$ experimental end-member.

Fig. 3. shows a negative relationship between rainfall DOC and $\mathrm{Hg}(\mathrm{II})$ photoreduction rate $\left(\mathrm{k}_{\mathrm{red}}, \mathrm{h}^{-1} ; \mathrm{r}^{2}=0.91\right)$. The relationship is driven by the PDM data which has lower DOC and faster $k_{\text {red }}$. Within the urban rainfall data, the DOC vs $k_{\text {red }}$ relationship remains significant, but less pronounced $\left(r^{2}=0.24\right)$ (Supplementary Fig. $\left.S 2\right)$. The variation in rainfall $k_{r e d}$ is not driven by $\mathrm{Hg} / \mathrm{DOC}$ ratio $\left(\mathrm{r}^{2}=0.14\right)$ (Supplementary Fig. S3). We observed no statistically significant ( $p>0.05)$ differences between rainfall $\mathrm{Hg}(\mathrm{II})$ reduction rates under natural $\left(0.063 \pm 0.026 \mathrm{~h}^{-1}, 2 \sigma\right.$, $\mathrm{n}=3)$ and simulated sunlight $\left(0.037 \pm 0.032 \mathrm{~h}^{-1}, 2 \sigma, \mathrm{n}=5\right)$. We suggest that the overall DOC vs. $\mathrm{k}_{\text {red }}$ trend in Fig. 3 is possibly driven by rainfall DOM molecular properties, likely to be different in the urban boundary layer and free troposphere. One possible reason may be the partial 
oxidation of thiol groups in atmospheric DOC at the remote PDM site (Tyndall and Ravishankara 1991). A lower availability of the high-affinity thiol ligands should result in weaker complexation of $\mathrm{Hg}$ (II) by low affinity $\mathrm{O} / \mathrm{N}$ ligands and therefore faster photoreduction rates (Jiang et al. 2015). A more detailed characterization of DOC is needed to understand this observation. Fig. 4. summarizes published $\mathrm{k}_{\mathrm{red}}$ and our experimental and rainfall $\mathrm{k}_{\mathrm{red}}$ observations. Rainfall $\mathrm{k}_{\mathrm{red}}$ are of similar magnitude as the lower (slower) end of $\mathrm{k}_{\mathrm{red}}$ in terrestrial and marine waters. Once more this points to differences in $\mathrm{OM}, \mathrm{Hg}-\mathrm{OM}$ properties and trace metal : $\mathrm{OM}$ ratios in atmospheric, terrestrial and marine waters. Understanding the influence of aquatic geochemistry on $\mathrm{Hg}$ photoreduction rates requires investigating all three water types with the same experimental and analytical techniques.

\section{Conclusions}

339 In this study we performed $\mathrm{Hg}(\mathrm{II})$ photoreduction experiments in the presence of halides $(\mathrm{Cl}, \mathrm{Br}$,

340 I) and DOC. The $\mathrm{Hg}(\mathrm{II})$ photoreduction rates observed in rainwater $\left(0.05 \mathrm{~h}^{-1}\right.$ in urban to $0.15 \mathrm{~h}^{-1}$ 341 in remote rainfall) are faster than those of isolated $\mathrm{HgBr}_{2}$ complexes $\left(0.004 \mathrm{~h}^{-1}\right)$, and resemble 342 more the rates of $\mathrm{Hg}(\mathrm{II})$-DOC compounds $\left(0.23 \mathrm{~h}^{-1}\right)$. Our observations on experimental and 343 rainfall $\mathrm{Hg}$ (II) photoreduction rates and on estimated $\mathrm{Hg}(\mathrm{II})$ speciation in rainfall lead to a 344 number of suggestions on cloud water $\mathrm{Hg}$ chemistry. Previous research on gas-phase $\mathrm{Hg}$ 345 chemistry has shown that elemental $\mathrm{Hg}$ emissions are partially oxidized by a two-step 346 mechanism, involving $\mathrm{Br}$ radicals in step 1 , and $\mathrm{NO}_{2}, \mathrm{HO}_{2}$ radicals in step 2, to produce $\mathrm{Hg}$ 347 halide end products $\mathrm{HgBr}_{2}, \mathrm{HgBrOH}, \mathrm{HgBrONO}, \mathrm{HgBrOHO}$ (Horowitz et al. 2017, Saiz-Lopez 348 et al. 2018). These gaseous oxidized $\mathrm{Hg}$ (II) compounds are water soluble and therefore partition 349 efficiently into aqueous aerosols and eventually in cloud water and rain (Amos et al. 2012, 
350 Horowitz et al. 2017). Aerosols contain abundant organic carbon, in large excess over halide ions, 351 which is reflected in the low halide/DOC ratios of rainfall observations $\left(0.04-0.75 \mathrm{~g} \mathrm{~g}^{-1}\right)$. 352 Despite the strong binding properties of halide ions towards $\mathrm{Hg}(\mathrm{II})$, our equilibrium $\mathrm{Hg}(\mathrm{II})$ 353 speciation calculations, and experimental photoreduction rate observations suggest that 354 scavenged $\mathrm{Hg}$-halide complexes are rapidly transformed into aqueous $\mathrm{Hg}$-DOC complexes in 355 rainfall, and by extension in cloud-water.

356 


\section{Acknowledgements}

359 This study has received funding from the European Research Council Executive Agency under

360 the European Union's Horizon 2020 Research and innovation programme (ERC-2010-STG 361258537 ) and from the H2020 ERA-PLANET (689443) iGOSP programme to JES. XY thanks 362 the China Scholarship Council (CSC) for this PhD grant. MJ received funding through the 363 H2020 Marie Sklodowska-Curie grant agreement 657195 and Swiss National Science 364 Foundation grant PZ00P2_174101. We thank the UMS 831 Pic du Midi Observatory team for 365 help with rainwater sampling, Franck Gilbert at EcoLab for use of the solar simulator, and Laure 366 Laffont for management of the Hg labs at GET.

Figures and tables 

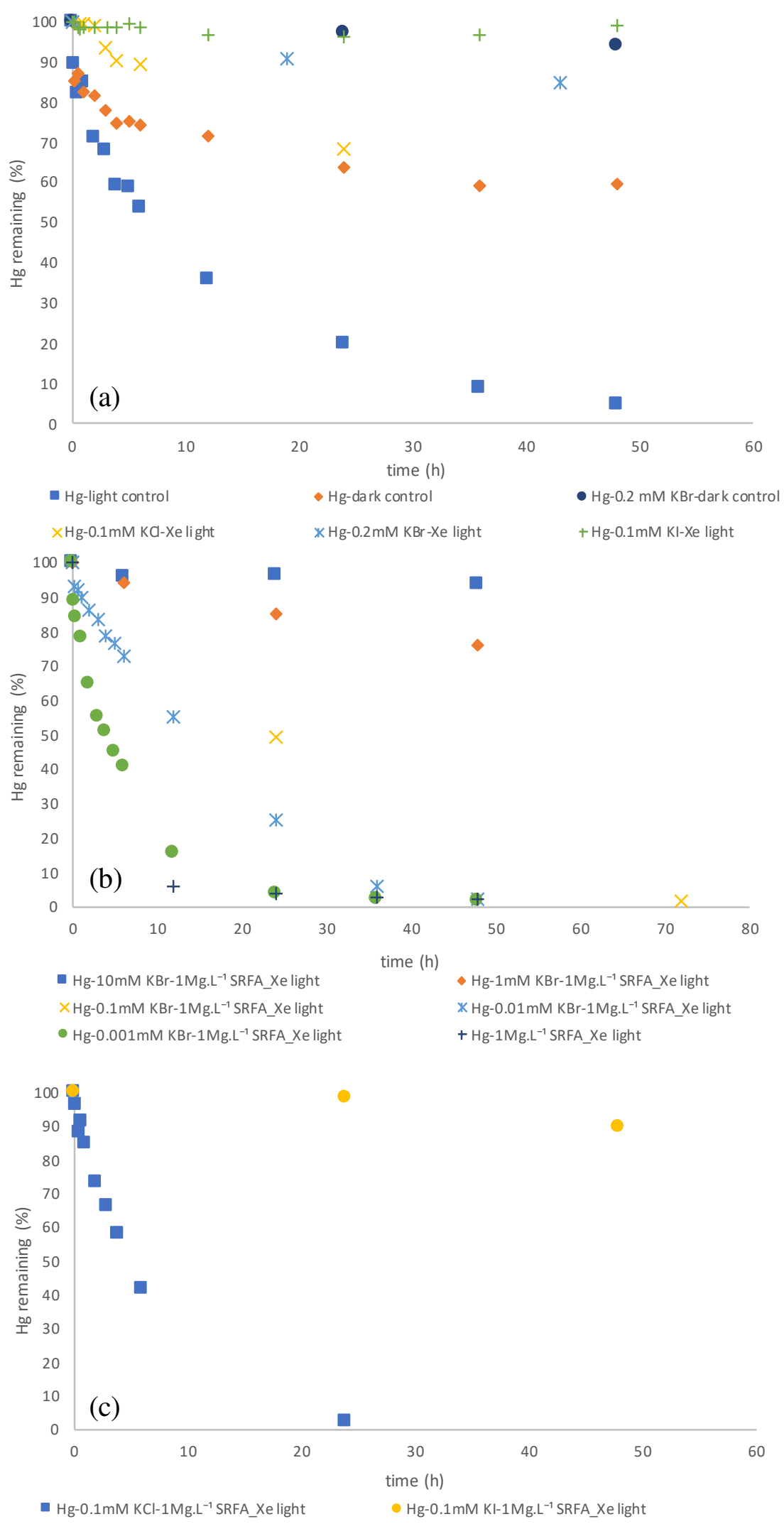

Page 19 of 29 
370 Figure 1a-c. Experimental photoreduction rates of 100ppb (0.5um) dissolved $\mathrm{Hg}$ (II) were carried 371 out: a) in the presence of different types of halides (experiment nos. A4-A6, table 1) and for light 372 and dark control experiments (experiments nos. A1-A3, table 1), b) in the presence of different $373 \mathrm{Br} / \mathrm{DOC}$ ratios (experiment nos. A7-A12, table 1), c) in the presence of different types of 374 halide/DOC (experiment nos. A13 and A14, table 1). SRFA, Suwannee river fulvic acid. 375

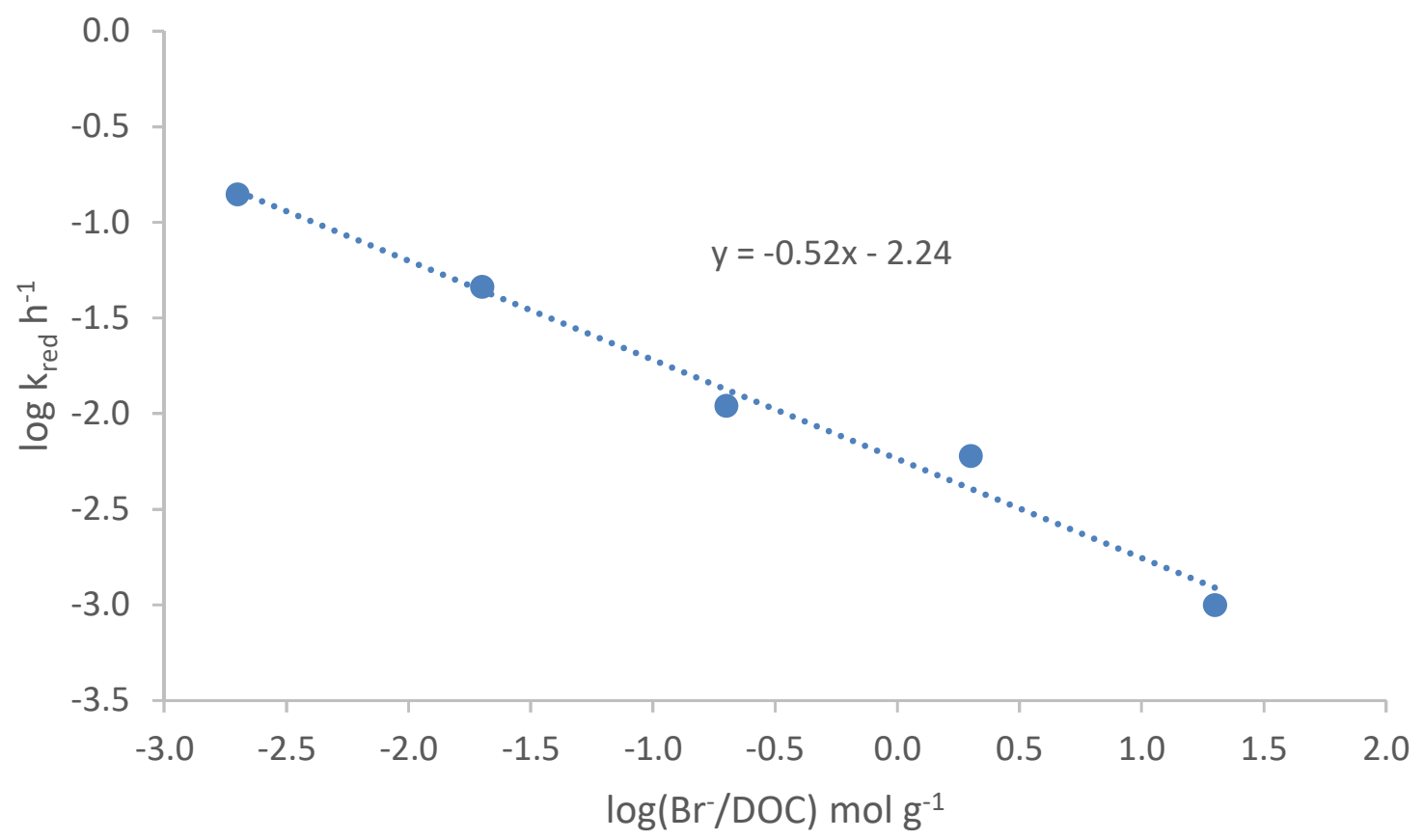

376

377 Figure 2. $\mathrm{Hg}$ (II) photoreduction rates are plotted against different $\mathrm{Br}$-/DOC ratios (experiments 378 A7-A11, Table 1). 


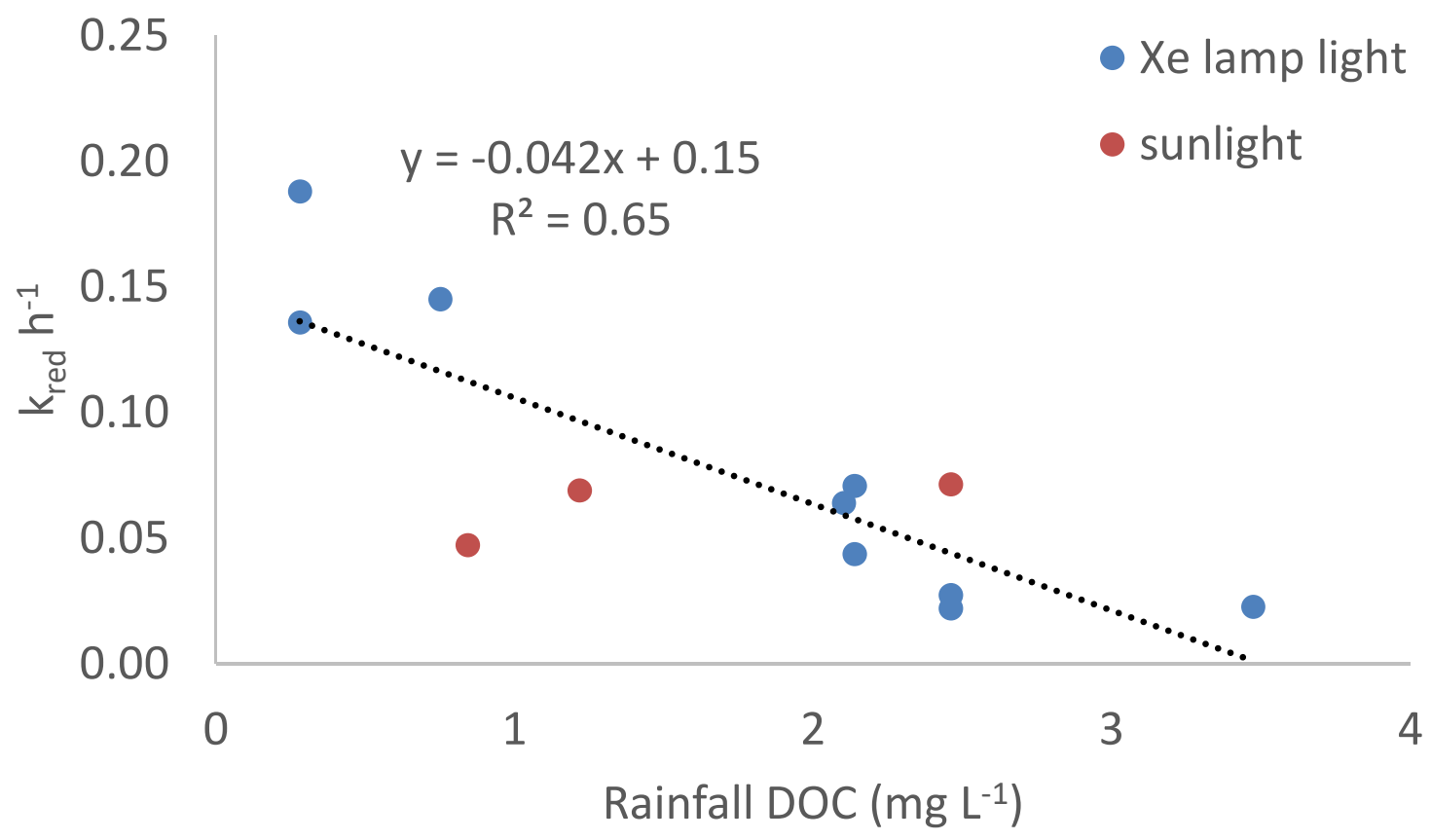

379

380 Figure 3. Rainfall DOC (mg. $\left.\mathrm{L}^{-1}\right)$ plotted as a function of rainfall $\mathrm{Hg}$ (II) photoreduction rate $\left(\mathrm{h}^{-1}\right)$

381 in the presence of xenon lamp light and natural sunlight. The regression line includes all data. 382 


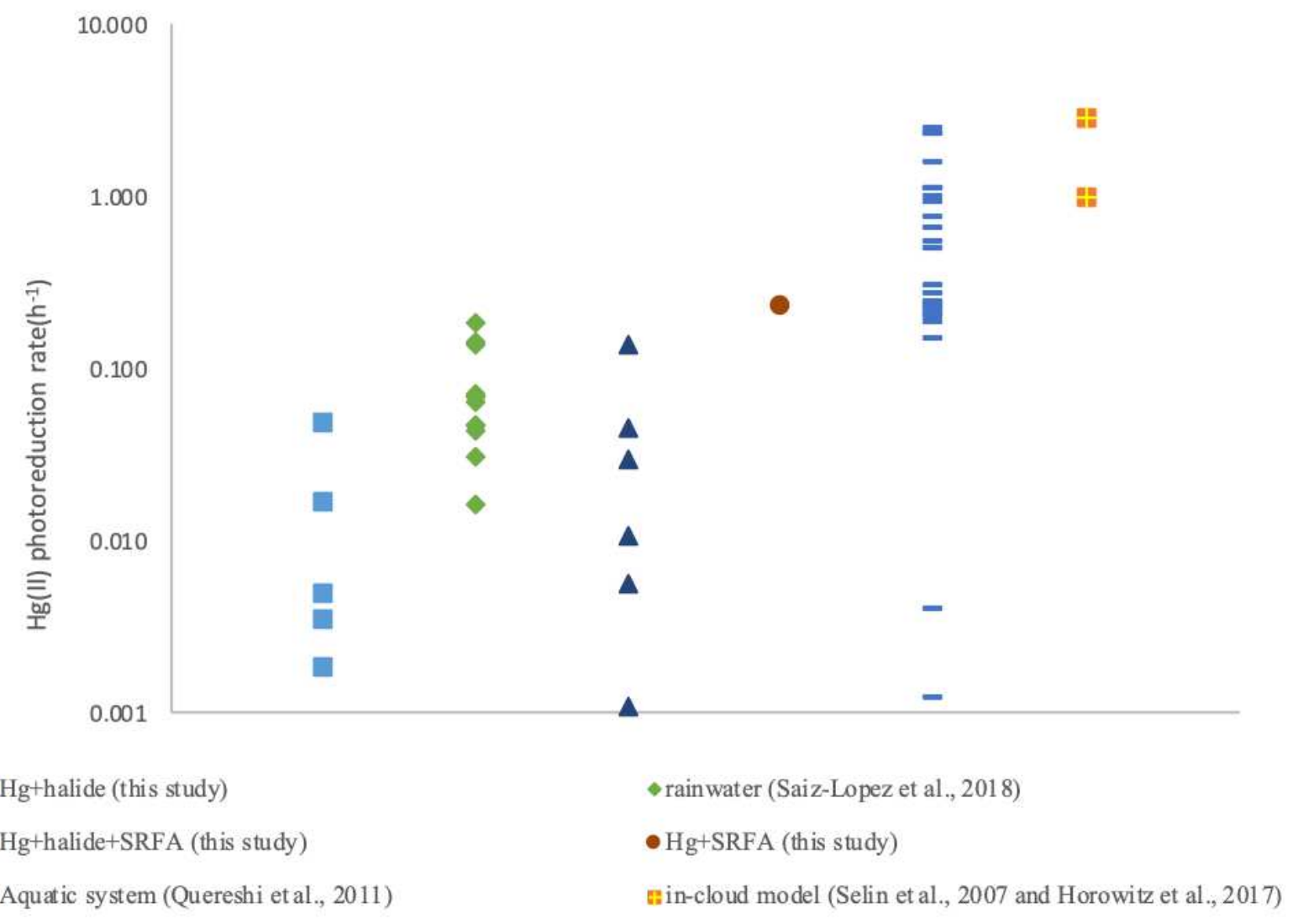

385 Figure. 4. Comparison of experimental and model photoreduction rates of $\mathrm{Hg}(\mathrm{II})$ in different 386 media. In-cloud model maximum $\mathrm{k}_{\text {red }}$ were approximated from the rate constant expressions in 387 Selin et al., 2007 (assuming typical, maximum [OH] of $10^{6}$ molecules $\mathrm{cm}^{-3}$ ), and Horowitz et al., 3882017 (assuming typical values of $\mathrm{jNO} 2$ of $10^{-2} \mathrm{~s}^{-1}$ and maximum organic aerosol levels, [OA] of $3891 \mu \mathrm{g} \mathrm{m}^{-3}$ ), and amount to $1 \mathrm{~h}^{-1}$, and $2.3 \mathrm{~h}^{-1}$ respectively. 
403 Table 1. Compositions and conditions of experimental $\mathrm{Hg}$ and rainfall solutions of

404 photoreduction experiments. A and $\mathrm{R}$ represent experimental $\mathrm{Hg}$ solution and rainfall solution.

$405 \mathrm{UF}$ and $\mathrm{F}$ indicate unfiltered and filtered rainfall. Xe represents xenon solar simulator. TL and

406 PDM indicate sub-urban Toulouse sample and high altitude (2877 m a.s.1.) Pic du Midi

407 Observatory samples. SRFA, Suwannee river fulvic acid; HgFA2 indicates Hg-fulvic acid

408 complex at strong type 2 sites in Visual Minteq.

\begin{tabular}{|c|c|c|c|c|c|c|c|c|c|c|c|c|c|}
\hline \multirow[t]{2}{*}{$\begin{array}{l}\text { Exp } \\
\text { no. }\end{array}$} & \multirow[t]{2}{*}{ Figure legend } & \multirow[t]{2}{*}{$\begin{array}{c}\text { dominant } \\
\mathrm{Hg} \\
\text { species }\end{array}$} & \multirow[t]{2}{*}{$\begin{array}{l}\mathrm{k}_{\mathrm{red}} \\
\mathrm{h}^{-1}\end{array}$} & \multirow[t]{2}{*}{$\mathrm{pH}$} & \multirow[t]{2}{*}{ Light } & $\mathrm{Hg}$ & DOC & $\begin{array}{l}\mathrm{Hg} / \mathrm{DO} \\
\mathrm{C}\end{array}$ & \multicolumn{2}{|c|}{ halide halide } & $\begin{array}{l}\text { SRF } \\
\text { A } \\
\text { mg.L }\end{array}$ & \multicolumn{2}{|c|}{$\begin{array}{l}\mathrm{Hg} / \text { halid halide/DO } \\
\mathrm{e} \quad \mathrm{C}\end{array}$} \\
\hline & & & & & & ng. $\mathrm{mL}^{-1}$ & mg. $\mathrm{L}^{-1}$ & ng.mg ${ }^{-1}$ & & $\mathrm{mM}$ & & $\mathrm{mg} \cdot \mathrm{mol}^{-1}$ & mol.g ${ }^{-1}$ \\
\hline A1 & Hg-Xe light & $\mathrm{Hg}(\mathrm{OH})_{2}$ & 0.022 & 4.1 & $\mathrm{Xe}$ & 100 & l & l & I & / & / & l & I \\
\hline $\mathrm{A} 2$ & Hg-dark control & $\mathrm{Hg}(\mathrm{OH})_{2}$ & 0.009 & 4.1 & Dark & 100 & / & l & I & l & / & I & I \\
\hline A3 & $\mathrm{Hg}-0.2 \mathrm{mM} \mathrm{KBr}$-dark control & $\mathrm{Hg}(\mathrm{Br})_{2}$ & 0.001 & 4.1 & Dark & 100 & l & l & $\mathrm{KBr}$ & 0.2 & l & 500 & l \\
\hline A4 & Hg-0.1mM KCl-Xe light & $\mathrm{Hg}(\mathrm{Cl})_{2}$ & 0.16 & 4.2 & $\mathrm{Xe}$ & 100 & / & l & $\mathrm{KCl}$ & 0.1 & I & 1000 & I \\
\hline A5 & $\mathrm{Hg}-0.2 \mathrm{mM} \mathrm{KBr}-\mathrm{Xe}$ light & $\mathrm{Hg}(\mathrm{Br})_{2}$ & 0.004 & 4.2 & $\mathrm{Xe}$ & 100 & / & / & $\mathrm{KBr}$ & 0.2 & / & 500 & / \\
\hline A6 & $\mathrm{Hg}-0.1 \mathrm{mM}$ KI-Xe light & $\mathrm{Hg}(\mathrm{I})_{2}$ & n.a. & 4.0 & $\mathrm{Xe}$ & 100 & l & / & $\mathrm{KI}$ & 0.1 & / & 1000 & I \\
\hline A7 & Hg-1mg/L SRFA-Xe light & $\mathrm{HgFA} 2$ & 0.23 & 7 & $\mathrm{Xe}$ & 100 & 0.5 & 200000 & / & / & 1 & / & / \\
\hline A 8 & $\begin{array}{l}\mathrm{Hg}-0.001 \mathrm{mM} \mathrm{KBr}-1 \mathrm{mg} / \mathrm{L} \text { SRFA-Xe } \\
\text { light }\end{array}$ & HgFA2 & 0.14 & 4.1 & $\mathrm{Xe}$ & 100 & 0.5 & 200000 & $\mathrm{KBr}$ & 0.001 & 1 & 100000 & 0.002 \\
\hline A9 & $\begin{array}{l}\mathrm{Hg}-0.01 \mathrm{mM} \mathrm{KBr}-1 \mathrm{mg} / \mathrm{L} \text { SRFA-Xe } \\
\text { light }\end{array}$ & $\mathrm{Hg}(\mathrm{Br})_{2}$ & 0.046 & 4.1 & $\mathrm{Xe}$ & 100 & 0.5 & 200000 & $\mathrm{KBr}$ & 0.01 & 1 & 10000 & 0.02 \\
\hline A10 & $\mathrm{Hg}-0.1 \mathrm{mM} \mathrm{KBr}-1 \mathrm{mg} / \mathrm{L}$ SRFA-Xe light & $\mathrm{Hg}(\mathrm{Br})_{2}$ & 0.011 & 4.1 & $\mathrm{Xe}$ & 100 & 0.5 & 200000 & $\mathrm{KBr}$ & 0.1 & 1 & 1000 & 0.2 \\
\hline A11 & $\mathrm{Hg}-1 \mathrm{mM} \mathrm{KBr}-1 \mathrm{mg} / \mathrm{L}$ SRFA-Xe light & $\mathrm{Hg}(\mathrm{Br})_{2}$ & 0.006 & 4.1 & $\mathrm{Xe}$ & 100 & 0.5 & 200000 & $\mathrm{KBr}$ & 1 & 1 & 100 & 2 \\
\hline A12 & Hg-10mM KBr-1mg/L SRFA-Xe light & $\mathrm{Hg}(\mathrm{Br})_{2}$ & 0.001 & 4.1 & $\mathrm{Xe}$ & 100 & 0.5 & 200000 & $\mathrm{KBr}$ & 10 & 1 & 10 & 20 \\
\hline A13 & Hg-0.1mM KCl-1mg/L SRFA-Xe light & $\mathrm{HgFA} 2$ & 0.16 & 4.2 & $\mathrm{Xe}$ & 100 & 0.5 & 200000 & $\mathrm{KCl}$ & 0.1 & 1 & 1000 & 0.2 \\
\hline A14 & Hg-0.1mM Kl-1mg/L SRFA-Xe light & $\mathrm{Hg}(\mathrm{I})_{2}$ & 0.002 & 7 & $\mathrm{Xe}$ & 100 & 0.5 & 200000 & KI & 0.1 & 1 & 1000 & 0.2 \\
\hline & & & & & & ng. $L^{-1}$ & & & $\begin{array}{l}\mathrm{F}^{-} \\
\mathrm{mg} . \mathrm{L}^{-}\end{array}$ & $\begin{array}{l}\mathrm{Cl}^{-} \\
\mathrm{mg} . \mathrm{L}^{-}\end{array}$ & $\begin{array}{l}\mathrm{Br}^{-} \\
\mathrm{mg} . \mathrm{L}^{-}\end{array}$ & $\begin{array}{l}\mathrm{I}^{-} \\
\mathrm{mg} \cdot \mathrm{L}^{-1}\end{array}$ & \\
\hline $\mathrm{R} 1$ & Rain event 1-U-Xe light-TL & $\mathrm{HgFA} 2$ & 0.043 & 4.7 & $\mathrm{Xe}$ & 9.0 & 2.14 & 4.2 & 0.02 & 0.88 & 0.002 & 0.0011 & 14.8 \\
\hline $\mathrm{R} 2$ & Rain event $1-\mathrm{U}-\mathrm{Xe}$ light-TL & HgFA2 & 0.071 & 4.4 & $\mathrm{Xe}$ & 82 & 2.14 & 38 & 0.02 & 0.88 & 0.002 & 0.0011 & 14.8 \\
\hline $\mathrm{R} 3$ & Rain event 2-F-Xe light-TL & $\mathrm{HgFA} 2$ & 0.064 & 4.1 & $\mathrm{Xe}$ & 89 & 2.10 & 42 & 0.02 & 0.26 & 0.002 & 0.0011 & 4.5 \\
\hline R4 & Rain event 3-U-Xe light-TL & $\mathrm{HgFA} 2$ & 0.016 & 6.3 & $\mathrm{Xe}$ & 89 & 3.47 & 26 & 0.02 & 0.19 & 0.003 & 0.0011 & 2.0 \\
\hline R5 & Rain event 4-F-Natural light-TL & HgFA2 & 0.069 & 6.1 & Sun & 88 & 1.42 & 62 & 0.01 & 0.091 & 0.001 & 0.0011 & 2.3 \\
\hline R6 & Rain event 5-F-Natural light-TL & $\mathrm{HgFA} 2$ & 0.047 & 6.3 & Sun & 91 & 0.84 & 108 & 0.01 & 0.63 & 0.002 & 0.0011 & 27.0 \\
\hline R7 & Rain event 5-F-Dark control-TL & $\mathrm{HgFA} 2$ & 0.007 & 6.3 & dark & 92 & 0.84 & 110 & 0.01 & 0.63 & 0.002 & 0.0011 & 27.0 \\
\hline $\mathrm{R} 8$ & Rain event 8-U-Natural light-TL & $\mathrm{HgFA} 2$ & 0.071 & 5.1 & sun & 2.6 & 2.46 & 1.0 & 0.01 & 0.1 & 0.001 & 0.0011 & 1.5 \\
\hline R9 & Rain event 8-U-Xe light-TL & HgFA2 & 0.047 & 5.1 & $\mathrm{Xe}$ & 2.5 & 2.46 & 1.0 & 0.01 & 0.1 & 0.001 & 0.0011 & 1.5 \\
\hline $\mathrm{R} 10$ & Rain event 8-U-Xe light-TL & $\mathrm{HgFA} 2$ & 0.031 & 3.8 & $\mathrm{Xe}$ & 103 & 2.46 & 42 & 0.01 & 0.1 & 0.001 & 0.0011 & 1.5 \\
\hline $\mathrm{R} 11$ & Rain event 9-U-Xe light-PDM & $\mathrm{HgFA} 2$ & 0.15 & 5.9 & $\mathrm{Xe}$ & 2.3 & 0.75 & 3.0 & 0.01 & 0.039 & n.a. & 0.0011 & 1.9 \\
\hline $\mathrm{R} 12$ & Rain event $10-\mathrm{U}-\mathrm{Xe}$ light-PDM & $\mathrm{HgFA} 2$ & 0.19 & 6.1 & $\mathrm{Xe}$ & 2.0 & 0.28 & 7.1 & 0.01 & 0.031 & n.a. & 0.0011 & 4.0 \\
\hline $\mathrm{R} 13$ & Rain event $10-\mathrm{U}-\mathrm{Xe}$ light-PDM & $\mathrm{HgFA} 2$ & 0.14 & 6.1 & $\mathrm{Xe}$ & 2.0 & 0.28 & 7.1 & 0.01 & 0.031 & n.a. & 0.0011 & 4.0 \\
\hline
\end{tabular}


409 Table 2. Equilibrium $\mathrm{Hg}(\mathrm{II})$ speciation of 100ppb $(0.5 \mu \mathrm{M})$ experimental $\mathrm{Hg}$ solutions and

410 rainfall solutions. /FA2 Hg indicates $\mathrm{Hg}$ (II) bound to the strong (type 2) fulvic acid (FA) sites in

411 the Stockholm Humic Acid model that simulates equilibrium $\mathrm{Hg}$ - humic interaction in the

\section{Visual Minteq software.}

\begin{tabular}{|c|c|c|c|c|c|c|}
\hline \multirow{2}{*}{\multicolumn{2}{|c|}{ Experiment no. Experiment name }} & \multicolumn{5}{|c|}{$\mathrm{Hg}(\mathrm{II})$ species and percentage } \\
\hline & & species $(\%)$ & species $(\%)$ & species $(\%)$ & species $(\%)$ & species $(\%)$ \\
\hline \multirow[t]{2}{*}{$\mathrm{A} 1 / \mathrm{A} 2$} & $\mathrm{Hg}+\mathrm{Xe}$ light/dark control & $\mathrm{Hg}^{2+}$ & $\mathrm{HgOH}^{+}$ & $\mathrm{Hg}(\mathrm{OH})_{2}$ & & \\
\hline & & 0.96 & 4 & 95 & & \\
\hline \multirow[t]{2}{*}{ A3/A5 } & $\mathrm{Hg}+0.2 \mathrm{mM} \mathrm{KBr}+$ dark control/Xe light & $\mathrm{HgBr}_{2}(\mathrm{aq})$ & $\mathrm{HgBr}_{3}^{-}$ & $\mathrm{HgBr}_{4}{ }^{2-}$ & $\mathrm{HgBrOH}(\mathrm{aq})$ & \\
\hline & & 95 & 5 & 0.02 & 0.01 & \\
\hline \multirow[t]{2}{*}{ A4 } & $\mathrm{Hg}+0.1 \mathrm{mM} \mathrm{KCl}+\mathrm{Xe}$ light & $\mathrm{HgCl}^{+}$ & $\mathrm{HgCl}_{2}(\mathrm{aq})$ & $\mathrm{HgCl}_{3}^{-}$ & $\mathrm{HgClOH}(\mathrm{aq})$ & $\mathrm{Hg}(\mathrm{OH})_{2}$ \\
\hline & & 0.21 & 97 & 0.10 & 3 & 0.02 \\
\hline \multirow[t]{2}{*}{ A6 } & $\mathrm{Hg}+0.1 \mathrm{mM} \mathrm{KI}+\mathrm{Xe}$ light & $\mathrm{HgI}_{2}(\mathrm{aq})$ & $\mathrm{HgI}_{3}^{-}$ & $\mathrm{HgI}_{4}{ }^{2-}$ & & \\
\hline & & 62 & 37 & 0.33 & & \\
\hline \multirow[t]{2}{*}{ A7 } & $\mathrm{Hg}+1 \mathrm{mg} / \mathrm{L}$ SRFA & $\mathrm{Hg}^{2+}$ & $/ \mathrm{FA} 2 \mathrm{Hg}(\mathrm{aq})$ & $\mathrm{HgOH}^{+}$ & $\mathrm{Hg}(\mathrm{OH})_{2}$ & \\
\hline & & 0.03 & 97 & 0.13 & 2.634 & \\
\hline \multirow[t]{2}{*}{ A8 } & $\mathrm{Hg}+0.001 \mathrm{mM} \mathrm{KBr}+1 \mathrm{mg} \cdot \mathrm{L}^{-1} \mathrm{SRFA}+\mathrm{Xe}$ light & $\mathrm{HgBr}^{+}$ & $\mathrm{HgBr}_{2}(\mathrm{aq})$ & $/ \mathrm{FA} 2 \mathrm{Hg}(\mathrm{aq})$ & $\mathrm{HgBrOH}$ & $\mathrm{Hg}(\mathrm{OH})_{2}$ \\
\hline & & 0.28 & 46 & 52 & 1.45 & 0.014 \\
\hline \multirow[t]{2}{*}{ A9 } & $\mathrm{Hg}+0.01 \mathrm{mM} \mathrm{KBr}+1 \mathrm{mg} . \mathrm{L}^{-1} \mathrm{SRFA}+\mathrm{Xe}$ light & $\mathrm{HgBr}^{+}$ & $\mathrm{HgBr}_{2}(\mathrm{aq})$ & $\mathrm{HgBr}_{3}^{-}$ & $/ \mathrm{FA} 2 \mathrm{Hg}(\mathrm{aq})$ & $\mathrm{HgBrOH}$ \\
\hline & & 0.02 & 70 & 0.16 & 30 & 0.13 \\
\hline \multirow[t]{2}{*}{ A10 } & $\mathrm{Hg}+0.1 \mathrm{mM} \mathrm{KBr}+1 \mathrm{mg} \cdot \mathrm{L}^{-1} \mathrm{SRFA}+\mathrm{Xe}$ light & $\mathrm{HgBr}_{2}(\mathrm{aq})$ & $\mathrm{HgBr}_{3}^{-}$ & $\mathrm{HgBrOH}$ & /FA2 Hg (aq) & \\
\hline & & 90 & 2 & 0.02 & 7 & \\
\hline \multirow[t]{2}{*}{ A11 } & $\mathrm{Hg}+1 \mathrm{mM} \mathrm{KBr}+1 \mathrm{mg} / \mathrm{L}$ SRFA+Xe light & $\mathrm{HgBr}_{2}(\mathrm{aq})$ & $\mathrm{HgBr}_{3}^{-}$ & $\mathrm{HgBr}_{4}{ }^{2-}$ & $/ \mathrm{FA} 2 \mathrm{Hg}(\mathrm{aq})$ & \\
\hline & & 77 & 18 & 0.34 & 5 & \\
\hline \multirow[t]{2}{*}{ A12 } & $\mathrm{Hg}+10 \mathrm{mM} \mathrm{KBr}+1 \mathrm{mg} / \mathrm{L}$ SRFA+Xe light & $\mathrm{HgBr}_{2}(\mathrm{aq})$ & $\mathrm{HgBr}_{3}^{-}$ & $\mathrm{HgBr}_{4}{ }^{2-}$ & $/ \mathrm{FA} 2 \mathrm{Hg}(\mathrm{aq})$ & \\
\hline & & 25 & 60 & 13 & 2 & \\
\hline \multirow[t]{2}{*}{ A13 } & $\mathrm{Hg}+0.1 \mathrm{mM} \mathrm{KCl}+1 \mathrm{mg} / \mathrm{L} \mathrm{SRFA}$ & $\mathrm{HgCl}^{+}$ & $\mathrm{HgCl}_{2}(\mathrm{aq})$ & $\mathrm{HgCl}_{3}^{-}$ & $/ \mathrm{FA} 2 \mathrm{Hg}(\mathrm{aq})$ & $\mathrm{HgClOH}(\mathrm{aq})$ \\
\hline & & 0.10 & 48 & 0.05 & 50 & 1.42 \\
\hline \multirow[t]{3}{*}{ A14 } & $\mathrm{Hg}+0.1 \mathrm{mM} \mathrm{KI}+1 \mathrm{mg} / \mathrm{L}$ SRFA & $\mathrm{HgI}_{2}(\mathrm{aq})$ & $\mathrm{HgI}_{3}^{-}$ & $\mathrm{HgI}_{4}^{2-}$ & $/ \mathrm{FA} 2 \mathrm{Hg}(\mathrm{aq})$ & \\
\hline & & 62 & 37 & 0.33 & 0.08 & \\
\hline & & Species $(\%)$ & percentage $(\%)$ & & & \\
\hline $\mathrm{R} 1$ & Rain event $1-\mathrm{U}-\mathrm{Xe}$ light-TL & /FA2Hg (aq) & 100 & & & \\
\hline $\mathrm{R} 2$ & Rain event $1-\mathrm{U}-\mathrm{Xe}$ light-TL & $/ \mathrm{FA} 2 \mathrm{Hg}(\mathrm{aq})$ & 100 & & & \\
\hline $\mathrm{R} 3$ & Rain event 2-F-Xe light-TL & /FA2Hg (aq) & 100 & & & \\
\hline
\end{tabular}

Page 24 of 29 


$\begin{array}{lcc}\text { Rain event 3-U-Xe light-TL } & \text { /FA2Hg (aq) } & 100 \\ \text { Rain event 4-F-Natural light-TL } & \text { /FA2Hg (aq) } & 100 \\ \text { Rain event 5-F-Natural light-TL } & / F A 2 H g(a q) & 100 \\ \text { Rain event 5-F-Dark control-TL } & / F A 2 H g(a q) & 100 \\ \text { Rain event 8-U-Natural light-TL } & / F A 2 H g(a q) & 100 \\ \text { Rain event 8-U-Xe light-TL } & / F A 2 H g(a q) & 100 \\ \text { Rain event 8-U-Xe light-TL } & / F A 2 H g(a q) & 100 \\ \text { Rain event 9-U-Xe light-PDM } & / F A 2 H g(a q) & 100 \\ \text { Rain event 10-U-Xe light-PDM } & / F A 2 H g(a q) & 100 \\ \text { Rain event 10-U-Xe light-PDM } & / F A 2 H g(a q) & 100\end{array}$

\section{References}

Amos, H. M., D. J. Jacob, C. D. Holmes, J. A. Fisher, Q. Wang, R. M. Yantosca, E. S. Corbitt, E. Galarneau, A. P. Rutter, M. S. Gustin, A. Steffen, J. J. Schauer, J. A. Graydon, V. L. St Louis, R. W. Talbot, E. S. Edgerton, Y. Zhang, and E. M. Sunderland. 2012. Gas-particle partitioning of atmospheric $\mathrm{Hg}(\mathrm{II})$ and its effect on global mercury deposition. Atmospheric Chemistry and Physics 12:591-603.

Ariya, P. A., M. Amyot, A. Dastoor, D. Deeds, A. Feinberg, G. Kos, A. Poulain, A. Ryjkov, K. Semeniuk, M. Subir, and K. Toyota. 2015. Mercury Physicochemical and Biogeochemical Transformation in the Atmosphere and at Atmospheric Interfaces: A Review and Future Directions. Chemical reviews 115:3760-3802.

Bash, J. O., A. G. Carlton, W. T. Hutzell, and O. R. Bullock. 2014. Regional Air Quality Model Application of the Aqueous-Phase Photo Reduction of Atmospheric Oxidized Mercury by Dicarboxylic Acids. Atmosphere 5:1-15.

Bergquist, B. A., and J. D. Blum. 2007. Mass-dependent and -independent fractionation of hg isotopes by photoreduction in aquatic systems. Science 318:417-420.

Dastoor, A. P. and Larocque, Y.: Global circulation of atmospheric mercury: a modelling study, Atmos. Environ., 38, 147-161, doi:10.1016/j.atmosenv.2003.08.037, 2004.

Deeds, D. A., A. Ghoshdastidar, F. Raofie, E.-A. Guerette, A. Tessier, and P. A. Ariya. 2015. Development of a Particle-Trap Preconcentration-Soft Ionization Mass Spectrometric Technique for the Quantification of Mercury Halides in Air. Analytical Chemistry 87:5109-5116. 
Del Vecchio, R., and N. V. Blough. 2002. Photobleaching of chromophoric dissolved organic matter in natural waters: kinetics and modeling. Marine Chemistry 78:231-253.

De Simone, F., Gencarelli, C. N., Hedgecock, I. M., and Pirrone, N.: Global atmospheric cycle of mercury: a model study on the impact of oxidation mechanisms, Environ Sci Pollut R, 21, 4110-4123, 10.1007/s11356-013-2451-x, 2014.

Dibble, T. S., M. J. Zelie, and H. Mao. 2012. Thermodynamics of reactions of $\mathrm{ClHg}$ and $\mathrm{BrHg}$ radicals with atmospherically abundant free radicals. Atmospheric Chemistry and Physics 12:10271-10279.

Enrico, M., G. Le Roux, N. Marusczak, L. E. Heimburger, A. Claustres, X. W. Fu, R. Y. Sun, and J. E. Sonke. 2016. Atmospheric Mercury Transfer to Peat Bogs Dominated by Gaseous Elemental Mercury Dry Deposition. Environmental Science \& Technology 50:2405-2412.

Ernest, C. T., D. Donohoue, D. Bauer, A. Ter Schure, and A. J. Hynes. 2014. Programmable Thermal Dissociation of Reactive Gaseous Mercury, a Potential Approach to Chemical Speciation: Results from a Field Study. Atmosphere 5:575-596.

Fu, X., N. Marusczak, L.-E. Heimbuerger, B. Sauvage, F. Gheusi, E. M. Prestbo, and J. E. Sonke. 2016. Atmospheric mercury speciation dynamics at the high-altitude Pic du Midi Observatory, southern France. Atmospheric Chemistry and Physics 16:5623-5639.

Futsaeter, G., and S. Wilson. 2013. The UNEP Global Mercury Assessment: Sources, Emissions and Transport.in N. Pirrone, editor. Proceedings of the 16th International Conference on Heavy Metals in the Environment.

Gardfeldt, K., J. Sommar, D. Stromberg, and X. B. Feng. 2001. Oxidation of atomic mercury by hydroxyl radicals and photoinduced decomposition of methylmercury in the aqueous phase. Atmospheric Environment 35:3039-3047.

Gustafsson, J. P. 2001. Modeling the Acid-Base Properties and Metal Complexation of Humic Substances with the Stockholm Humic Model. Journal of Colloid and Interface Science 244:102-112.

Haitzer, M., G. R. Aiken, and J. N. Ryan. 2002. Binding of mercury(II) to dissolved organic matter: The role of the mercury-to-DOM concentration ratio. Environmental Science \& Technology 36:3564-3570. 
Horowitz, H. M., D. J. Jacob, Y. X. Zhang, T. S. Dibble, F. Slemr, H. M. Amos, J. A. Schmidt, E. S. Corbitt, E. A. Marais, and E. M. Sunderland. 2017. A new mechanism for atmospheric mercury redox chemistry: implications for the global mercury budget. Atmospheric Chemistry and Physics 17:6353-6371.

Horvath, O., and A. Vogler. 1993. PHOTOREDOX CHEMISTRY OF CHLOROMERCURATE(II) COMPLEXES IN ACETONITRILE. Inorganic Chemistry 32:5485-5489.

Jiang, T., U. Skyllberg, S. Wei, D. Wang, S. Lu, Z. Jiang, and D. C. Flanagan. 2015. Modeling of the structure-specific kinetics of abiotic, dark reduction of $\mathrm{Hg}(\mathrm{II})$ complexed by $\mathrm{O} / \mathrm{N}$ and $\mathrm{S}$ functional groups in humic acids while accounting for time-dependent structural rearrangement. Geochimica et Cosmochimica Acta 154:151-167.

Jiskra, M., J. E. Sonke, D. Obrist, J. Bieser, R. Ebinghaus, C. L. Myhre, K. A. Pfaffhuber, I. Wangberg, K. Kyllonen, D. Worthy, L. G. Martin, C. Labuschagne, T. Mkololo, M. Ramonet, O. Magand, and A. Dommergue. 2018. A vegetation control on seasonal variations in global atmospheric mercury concentrations. Nature Geoscience 11:244-+.

Lin, C. J., and S. O. Pehkonen. 1999. The chemistry of atmospheric mercury: a review. Atmospheric Environment 33:2067-2079.

Maizel, A. C., and C. K. Remucal. 2017. Molecular Composition and Photochemical Reactivity of Size-Fractionated Dissolved Organic Matter. Environ Sci Technol 51:2113-2123.

Marusczak, N., J. E. Sonke, X. W. Fu, and M. Jiskra. 2017. Tropospheric GOM at the Pic du Midi Observatory-Correcting Bias in Denuder Based Observations. Environmental Science \& Technology 51:863-869.

Munthe, J., Z. F. Xiao, and O. Lindqvist. 1991. THE AQUEOUS REDUCTION OF DIVALENT MERCURY BY SULFITE. Water Air and Soil Pollution 56:621-630.

O'Driscoll, N. J., S. D. Siciliano, D. R. S. Lean, and M. Amyot. 2006. Gross photoreduction kinetics of mercury in temperate freshwater lakes and rivers: Application to a general model of DGM dynamics. Environmental Science \& Technology 40:837-843.

Pehkonen, S. O., and C.-J. Lin. 1998. Aqueous photochemistry of mercury with organic acids. Journal of the Air \& Waste Management Association 48:144-150. 
Peleg, M., E. Tas, D. Obrist, V. Matveev, C. Moore, M. Gabay, and M. Luria. 2015. Observational Evidence for Involvement of Nitrate Radicals in Nighttime Oxidation of Mercury. Environmental Science \& Technology 49:14008-14018.

Qureshi, A., M. MacLeod, E. M. Sunderland, and H. Konrad. 2011. Exchange of Elemental Mercury between the Oceans and the Atmosphere. Pages PP 389-421 In Environmental Chemistry and Toxicology of Mercury; Liu, G.; Cai, Y.; O’Driscoll, N. J., Eds.; John Wiley \& Sons, Inc: Hoboken, NJ.

Ravichandran, M. 2004. Interactions between mercury and dissolved organic matter--a review. Chemosphere 55:319-331.

Richard, J. H., C. Bischoff, and H. Biester. 2016. Comparing Modeled and Measured Mercury Speciation in Contaminated Groundwater: Importance of Dissolved Organic Matter Composition. Environmental Science \& Technology 50:7508-7516.

Saiz-Lopez, A., S. P. Sitkiewicz, D. Roca-Sanjuan, J. M. Oliva-Enrich, J. Z. Davalos, R. Notario, M. Jiskra, Y. Xu, F. Wang, C. P. Thackray, E. M. Sunderland, D. J. Jacob, O. Travnikov, C. A. Cuevas, A. U. Acuna, D. Rivero, J. M. C. Plane, D. E. Kinnison, and J. E. Sonke. 2018. Photoreduction of gaseous oxidized mercury changes global atmospheric mercury speciation, transport and deposition. Nature Communications 9.

Schroeder, W. H., and J. Munthe. 1998. Atmospheric mercury - An overview. Atmospheric Environment 32:809-822.

Selin, N. E. 2009. Global Biogeochemical Cycling of Mercury: A Review. Annual Review of Environment and Resources 34:43-63.

Selin, N. E., D. J. Jacob, R. J. Park, R. M. Yantosca, S. Strode, L. Jaegle, and D. Jaffe. 2007. Chemical cycling and deposition of atmospheric mercury: Global constraints from observations. Journal of Geophysical Research-Atmospheres 112.

Shia, R. L., C. Seigneur, P. Pai, M. Ko, and N. D. Sze. 1999. Global simulation of atmospheric mercury concentrations and deposition fluxes. Journal of Geophysical ResearchAtmospheres 104:23747-23760.

Si, L., and P. A. Ariya. 2008. Reduction of oxidized mercury species by dicarboxylic acids $(C(2)-C(4))$ : Kinetic and product studies. Environmental Science \& Technology 42:51505155 . 
Suess, E., F. Aemisegger, J. E. Sonke, M. Sprenger, H. Wernli, and L. H. E. Winkel. 2019. Marine versus Continental Sources of Iodine and Selenium in Rainfall at Two European High-Altitude Locations. Environmental Science \& Technology 53:1905-1917.

Travnikov, O., and A. Ryaboshapko. 2002. MODELLING OF MERCURY HEMISPHERIC TRANSPORT AND DEPOSITION.

Tyndall, G. S., and A. R. Ravishankara. 1991. ATMOSPHERIC OXIDATION OF REDUCED SULFUR SPECIES. International Journal of Chemical Kinetics 23:483-527.

Van Loon, L., E. Mader, and S. L. Scott. 2000. Reduction of the aqueous mercuric ion by sulfite: UV spectrum of $\mathrm{HgSO} 3$ and its intramolecular redox reaction. Journal of Physical Chemistry A 104:1621-1626.

Wolfe, M. F., S. Schwarzbach, and R. A. Sulaiman. 1998. Effects of mercury on wildlife: A comprehensive review. Environmental Toxicology and Chemistry 17:146-160.

Xiao, Z., J. Munthe, D. Strömberg, and O. Lindqvist. 1994. Photochemical behaviour of inorganic mercury compounds in aqueous solution. Mercury Pollution; Integration and Synthesis, CJ Watras and JW Huckabee (Eds.):581-592.

Xiao, Z. F., D. Stromberg, and O. Lindqvist. 1995. INFLUENCE OF HUMIC SUBSTANCES ON PHOTOLYSIS OF DIVALENT MERCURY IN AQUEOUS-SOLUTION. Water Air and Soil Pollution 80:789-798.

Zhang, H. 2006. Photochemical redox reactions of mercury. Pages 37-79 in D. A. Atwood, editor. Recent Developments in Mercury Science.

Zheng, W., and H. Hintelmann. 2009. Mercury isotope fractionation during photoreduction in natural water is controlled by its $\mathrm{Hg} / \mathrm{DOC}$ ratio. Geochimica et Cosmochimica Acta 73:6704-6715. 
